\title{
Hotel management and operations options: Intellectual capital versus financial capital
}

Received (in revised form): 19 November 2003

\section{Martin Armitstead}

is Director of Hotels for Colliers RH, an international residential property and hotel consultancy in London. He leads a specialist team covering agency assignments and providing expert advice and development services across a whole range of domestic and international hotel development opportunities. Current assignments range from luxury destination resorts to full-service city centre hotels; budget and 'boutique' opportunities to market repositioning exercises. Colliers RH specialises in site selection, project appraisal, project finance, operator selection and contract negotiation, asset management and strategic advice. Prior to joining Colliers RH Martin held senior development positions with Regent International, Conrad International, Copthorne Hotels and Trust House Forte, and has personally undertaken assignments in more than 50 countries, exposing him to a full range of cultures, diverse opportunities, markets and deal structures.

\section{Abstract}

This paper examines the options for contracts and deal structures with hotel management companies, and highlights some of the trends and issues that need to be considered when embarking on the selection of an operating partner. Following the shake-out in the hospitality industry caused by the events and turmoil of the past two years, there is now renewed activity, with renewed optimism and interest from developers in most sectors in both the UK and many international and resort markets. At the same time some new operators are emerging who are prepared to do more flexible and creative deals, and tailor the contracts more specifically to the owner developer needs, but who - until they have the brand presence - do not have the same 'muscle' as the major hotel groups. So how does one try to achieve the right balance?

\section{Keywords:}

balancing risk, striking a fair balance, achieving a bankable management contract

Martin Armitstead

Colliers RH

Nash House

Mayfair

London W1S 1 FQ, UK

Tel: +44 (o) 2074919791

Fax: +44(0)2074919792

E-mail: marmitstead@colliersrh.co.uk
The history of management contracts in the hotel industry has been well documented, but the changing trends and alternative options have been less well covered. There is an evolution going on which is slowly but surely changing the balance of risk in favour of the owner of a hotel, and putting a greater onus on operators to 'perform' as custodians and managers of the investment. Traditionally anyone wanting to secure the services of one of the 
better management companies more or less had to accept the standard contracts that were offered; but as a consequence of several factors this is now changing. The factors that have brought about this sea change include the ongoing 'monopoly' in the hotel real estate business, the fact that some of the larger companies have not been immune to global economic circumstances (witness Le Meridien) and a growing number of smaller hotel companies emerging with an appetite for growth and a desire to build their brand, who are prepared to undertake more flexible contracts in order to do this.

For a management company the issues are normally as follows.

- How much do we want/need a 'flag' in this location?

- Will it add value long term to the group and the share price?

- Who is the 'owner' and do they have the financial means to support and deliver the project?

- Do we have the distribution channels and customer base to deliver the business to the hotel?

- What is the downside risk?

- Might business to other group hotels be diluted as a consequence of this contract?

- What is the risk associated with the location (geographic, political, economic)?

For the owner the issues can be far wider.

- Are these people I can work with and trust?

- Can they deliver the customers?

- Will they be (so far as can be assessed) long-term players?

- Where will they support the operations from, and what will this cost me?

- Are there any hidden charges or costs?

\section{Owner issues}

- How well do they know the market or will they have to learn at my expense?

- Can I get rid of them if they do not perform or if I want to sell the hotel?

- Will they pay me a minimum sum each year to cover my debt service?

— Will they share the pain of underperformance?

The basic issue in negotiating any management agreement is therefore about the apportionment of risk, and to do this the owner needs to understand the options available to him. There is no 'right' or 'best' solution - each project is different, operators will view some locations as priorities where they will take risk and other locations where they will not - and each owner will have a different position also. 


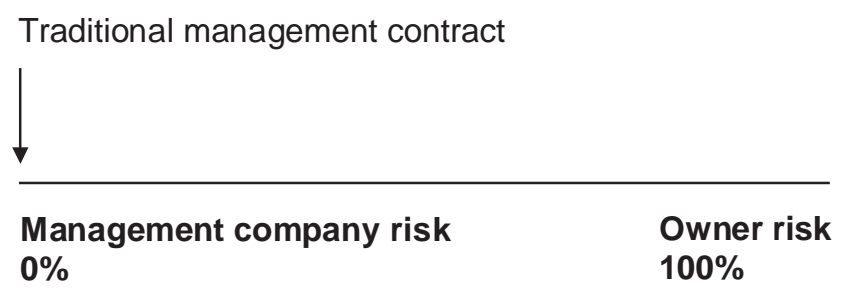

Figure 1: The traditional management contract

\section{THE TRADITIONAL MANAGEMENT CONTRACT}

In the traditional management contract (Figure 1), the owner develops the hotel and provides all the finance for it, as well as providing the finance for the working capital and pre-opening costs, and funding any losses.

The operator or management company provides the 'intellectual'

\section{A traditional approach} management, and manage the hotel on behalf of the owner, supporting this with sales and marketing, and access to the reservation and distribution systems, loyalty programmes etc.

Typically the operator is paid a percentage of the top-line revenues ( 3 per cent), and a percentage of the gross operating profit (GOP) (typically 10 per cent) — with GOP being the profit before the fixed charges of property taxes, buildings insurance and a reserve established for the replacement of the furniture, fittings and equipment (FF\&E). It is important to note that 100 per cent of the risk stays with the owner, and normally all staff - except perhaps the general manager - are employees of the owner.

Typically management agreements are for 20 years, although many of the established hotel brands will seek much longer terms than this (35-50 years and with extensions to renew). Smaller and emerging groups will often agree on an initial term of ten years.

An owner needs to remember that a management contract of this type encumbers the property, and would restrict its appeal if offered for sale. It could reduce the open market value by up to 20 per cent, although management companies will argue that the additional revenue and profit they generate will offset this against a hotel managed by an independent operator.

Some operators will consider a management fee based purely on the profit of the hotel and with no turnover-related base fee. Typically this would be in the order of 16-20 per cent of GOP/ adjusted gross operating profit (AGOP). Many industry gurus do not feel this is appropriate except in some exceptional circumstances, as the operator will 'sweat' the business, and possibly cut back on maintenance etc in order to increase the shortterm profitability, and in turn their fees.

In the 'lease' the operating risk shifts totally to the operator (Figure 2). They manage the business as their own, and retain all profits after paying the rent. This provides a 'guaranteed' income to 


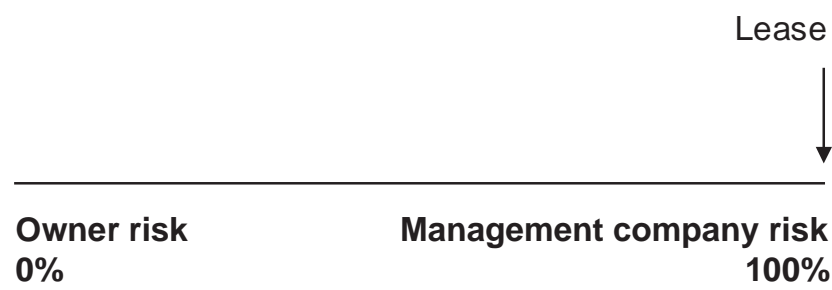

Figure 2: Lease

the owner (subject to the covenant of the operator and increasingly difficult to assess), but in the event that the hotel does very well then there is no upside to the owner - it all remains with the operator.

Typically leases are 15 to 20 years. Operators will try to fix the rent in advance, or have it indexed to 70 per cent of the change in the retail price index. Yields will reflect the market norm, and the strength of the negotiating hand.

Norms are that the rent should be in the range of 18-22 per cent of the stabilised annual revenue, and operators will look to see that forecast profit will cover rent by $120-140$ per cent. Some recent sale and leasebacks have indicated a rent of around 28 per cent of sales, but these are generally in cases where the operator has managed the business for many years and knows the property and market well. Yields against capital cost can be in the order of 6-9 per cent, the variables here being the covenant strength of the operator and the levels of any guarantees that may be given.

The recent market volatility has meant that leases have lost some of their appeal to operators - the demise of Dorint being a good example of a company that was overexposed to leases in its portfolio.

It should be further noted that under US general accounting principles, US corporations have to consolidate the full contingent liability of the lease on their balance sheet, and therefore few US hotel companies will enter into this type of agreement.

\section{OPERATOR EQUITY}

Some management companies will participate in the share capital of an owning company, or alternatively give some 'soft' loans to it to assist in funding the development (Figure 3). In some cases, for example, operators may fund the working capital and pre-opening costs (these could be in the region of $€ 2-2.5 \mathrm{~m}$ ), or they may even fund the FF\&E.

The 'equity' that hotel companies put in generally is 'expensive' money in that they will be less flexible in the management agreement terms and conditions, and will reflect the required return on investment hurdles they have in the fee structure. Typically companies will offer 10-20 per cent, and in some strategic cities/ locations perhaps up to 25 per cent. 


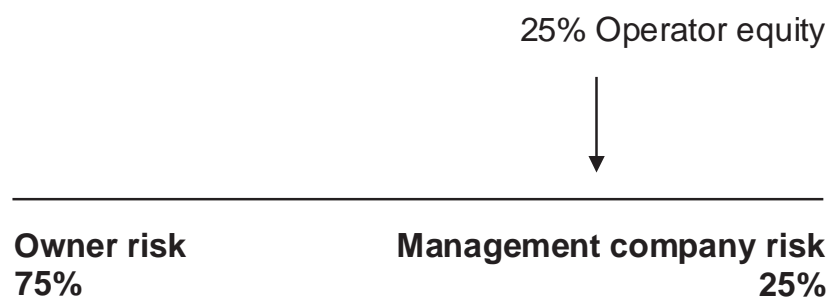

Figure 3: Operator equity

While the operator can therefore claim to be sharing in the risk of the venture, few will take any risk associated with construction costs, and will only make the equity contribution at the end of any build/ development programme. From an owner's point of view this is not ideal, as equity is normally expended before debt on any new-build hotel project. There is then an additional layer required in the documentation through the need for a shareholder agreement, and care needs to be taken with regard to looking at exit mechanisms, as the operator will want to remain in control of the hotel.

One final consideration is that the industry is seeing far fewer stand-alone hotels built now, and more hotels that are part of mixeduse schemes, where the success of the hotel is in part dependent on the success of the remainder of the development. This will often be reflected in the deal to be done, with operators seeking to ensure the quality of any adjacent commercial or residential areas is maintained, and further looking for guarantees that vacancy rates do not exceed a pre-determined level without some form of penalty.

\section{TURNOVER LEASE}

Some management companies look to redress the balance of the normal lease and offset some of their 'risk' by either offering a turnover lease or a lease with a low fixed/guaranteed element and a variable profit share (Figure 4).

Clearly the level of risk will be dependent on where the fixed and variable rents are struck. Owners can benefit significantly in times when the hotel does well, but will shoulder some risk in a market downturn. Care needs to be taken to define the rents closely, and to ensure that the projections used to support the project are robust and not overly optimistic.

Turnover lease

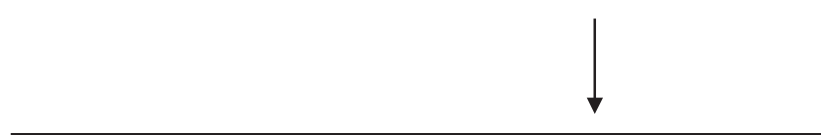


Performance guarantees

\section{OPERATOR STAND-ASIDE OR SUBORDINATION OF FEES}

In an effort to try and strike a deal and find common ground on 'risk', most operators are prepared to stand aside or defer all or part of their incentive fee (and in some cases base and incentive fees) in favour of a preferred owner's return (Figure 5). Normally this is done at a level equivalent to the cash required to service the debt on the property, and operators will require the contract to stipulate the maximum amount of gearing, and cap the interest rate and the level of borrowing, so that the factors outside their control are effectively ring-fenced.

Where an operator does stand aside from a fee they will often do so on the basis that the deferred fees are transferred into a subordinated interest-bearing loan to be repaid as a priority after future profits, or in some cases the ability to convert into preference shares. In the author's experience, while this helps, and gives some comfort to financiers, the risk still remains substantially with the owner.

\section{OPERATOR GUARANTEES}

An increasingly popular scenario is where an operator will provide a guarantee, whereby if a pre-agreed level of performance is not met then they will provide a guarantee and make up the shortfall (Figure 6). Again this is usually for a level of debt service (as opposed to a return on equity), and operators will usually only provide 'cash' after a stand-aside of the incentive fee as in the previous section.

Some operators will provide the guarantee during the riskier earlier years of the hotel while it is becoming established; others see this as being the owner's risk, and will provide the guarantee from stabilisation - typically year three to year five depending on the

Deferral of incentive fee

\begin{tabular}{lr} 
& $\mid$ \\
\hline Owner risk & Management company risk \\
$80 \%$ & $20 \%$
\end{tabular}

Figure 5: Operator stand-aside

\begin{tabular}{ll} 
& Operator guarantee \\
\hline $\begin{array}{l}\text { Owner risk } \\
70 \%\end{array} \quad$ Management company risk \\
$30 \%$
\end{tabular}




\section{Key requirements}


owner's control, and discusses with the owner how much involvement they actually want or if they feel it is appropriate to have an asset manager to monitor and interface with the operator on a regular basis.

The company also endeavours to stimulate competition between operators in order to extract better terms, and this requires a proper approach to the market and to hotel management companies. The company feels that the owner must have appropriate controls and authority, rights and sanctions in the contract. These will depend on individual circumstances.

So finally, what are some of the other issues? A management contract is in some ways like any other relationship. It has to be worked on, it has to be transparent, based on trust and there has to be communication on a regular basis by both sides. In contracts Colliers RH is advising on, it recommends the following.

- Seek a clause giving the owner the right to terminate in the event that there is a change of ownership of the operating company (perhaps after a period of time to evaluate the change), or frequent changes of management or area management personnel. Clearly the owner does not have to terminate - but operators must realise that if they change senior management frequently this can cause disruption to the business, and owners might suffer a reduction in performance as a consequence.

- Set reasonable performance targets, either against agreed budgets, debt service ability or competition in the market, and alongside these reasonable sanctions if the performance criteria are not met. Consider the ultimate sanction of termination for repeated failure to perform. Operators should devise realistic criteria for performance and have these as standard clauses in contracts.

- No operator usually wants to suffer the indignation of termination. But in addition to termination for performance (lack of), the owner should have the option to terminate if the operator commences operation of another competing hotel within a defined territory (and therefore there is a clear conflict of interest) or on sale of the asset. In the latter case it is usual for the operator to seek compensation for the termination of the contract, and once again this should be 'reasonable'.

- Make it clear in the contract that the operator may not take any other fees or make any recharges to the business other than those agreed in the contract or as part of the annual budget process. It is sometimes very difficult to determine if some group initiatives will benefit some hotels more than others.

- Seek a clause whereby if the hotel makes a loss then the operator takes no fees. Share the risk and the rewards. It has always seemed unfair that all the downside risk stays with the owner, and that an operator could take fees when the business is losing money. 